\title{
ANALYSIS OF THE EFFECTIVENESS OF SKILL TRAINING AND MOTIVATION ON THE GROWTH OF ENTREPRENEURIAL INTEREST ON MEMBERS OF SETIA BHAKTI WANITA EAST JAVA WOMEN COOPERATIVE
}

\author{
Iwang Suwangsih \\ Department Management of Economic and Business \\ Faculty of Airlangga University
}

\begin{abstract}
The purpose of this study is to analyze whether skills training or short course which had been done by woman cooperative can grow entrepreneurial interest on woman cooperative's members. The purpose of cooperatives is to provide entrepreneurial skills, namely to encourage members to become entrepreneurs, which will certainly have an impact on cooperative performance because if many members are entrepreneurs, so they will participate actively to cooperatives. The sampling technique used was simple random sampling with 100 respondents as samples. The result of this study concluded that skills training variable simultaneously and partially have significant effect on entrepreneurial interest of woman cooperative's members.
\end{abstract}

Keywords: training skill, motivation, entrepreneurial interest

\section{INTRODUCTION}

In this globalization era, business competition is increasing, and economic conditions are increasingly becoming more difficult, causing many companies to close down and also impacting on the increasing number of the unemployed. To overcome this, the government encourages people to become entrepreneurs by providing a variety of training for free and is very supportive of the emergence of SMEs. The government not only provides free training but also provides capital assistance. The spirit of entrepreneurship will continue to be fostered in

\footnotetext{
*Corresponding Author.

e-mail: iwang.suwangsih-m.m-2017@feb.unair.ac.id
} 
many circles in various environments (Munir, Idrus, Shukur, Ithnin, \& Mohamad, 2015).

According to Yunus $(2008$, p.270) entrepreneurs have a very vital role for humanity, which can change the lives of the bottom $60 \%$ of the world's population and help them get out of economic problems. The economy of a nation will improve when the interest of community entrepreneurship is sufficiently high (Sugiarto, Wismanto, \& Utami, 2015). For these reasons, the government of Indonesia supports the growth of cooperatives and small medium enterprises in Indonesia by giving some entrepreneurial training to Indonesian society because the role of entrepreneurs is really needed by a country as it also determines the success of national development (Josia Sanchaya Hendrawan, 2017).

Entrepreneurs are not people who choose all businesses in all fields, but they study them, observe closely, find information from the data they want to know, and then move with their intuition and knowledge to build a business (Sugiarto et al., 2015). To become an entrepreneur, a person must be interested in entrepreneurship because that will motivate him to determine the type of business he will pursue. Someone will be more eager to do something if he is interested in the job.

According to Sugiarto et al. (2015), to make an entrepreneur, the interest of entrepreneurship needs to be instilled in the school environment by having some trainings to introduce and foster interest in entrepreneurial students. Their result stated that entrepreneurial skills training programs can foster student entrepreneurship interest, so as to encourage students to explore something they are interested in and move to real actions directed and oriented towards entrepreneurship.

Entrepreneurial interest can be done through skills training guidance program. Cultivating the interest in entrepreneurship can be done with a touch of attention, feeling, and motivation. Entrepreneurial motivation is considered vital because it is considered to play a role in translating intentions into entrepreneurial actions (Rahmi \& Hidayati, 2019). Motivation to be an entrepreneur is driven by the attractiveness of entrepreneurship and the attraction of working for others (Munir et al., 2015). The results of Rahmi and Hidayati's research stated that the direct effect of skills training on entrepreneurial interest is greater than the value 
of the indirect effect of skills training on entrepreneurial interest through motivating the entrepreneurial self.

According to Meredith (1996), the growth of entrepreneurial interest cannot be done immediately without education and training that can move one's entrepreneurial spirit (Josia Sanchaya Hendrawan, 2017). Widyana (2018) stated that the provision of entrepreneurship courses and entrepreneurship training in the creative economy that has been conducted at FE of Unmas Denpasar is proven to be able to increase the interest of creative entrepreneurs among their students (Widyana, Widyawati, \& Warmana, 2018).

Cooperatives as social organizations is one of the pillars of Indonesia's national development as it is expected to overcome the problem of unemployment. There are many kinds of cooperatives in Indonesia, one of them is women's cooperative. Nowadays, women's cooperatives are developing quite rapidly. Based on the Online Data System (ODS) of the Ministry of Cooperatives and SMEs, as of April 20, 2018 there were 13,212 active women's cooperative units and 4,631 had obtained certificates of Cooperative Master-Number (NIK).

Seeing the potential of women for entrepreneurship, the Government of Indonesia aims to empower women to play an active role in developing their potential for entrepreneurship so that they can increase their family income through women's cooperatives as a forum because as members of cooperatives, they can get the capital needed for entrepreneurship from cooperatives. Besides that, cooperatives that have self-identity will carry out the principles of cooperatives, one of which is to provide education for members. Education provided to members aims to improve the human resources of members, both about cooperatives or other trainings such as entrepreneurship skills.

Setia Bhakti Wanita (SBW) Jawa Timur Cooperative is one of the Women Cooperatives which have membership of around 13 thousand individuals. As a good cooperative, the Setia Bhakti Wanita cooperative also implements cooperative principles, one of which is providing education to members of the cooperative to improve the members' human resources, both in education about cooperatives and entrepreneurship skills. Considering that the majority of cooperative members $(50 \%$ are housewives, by providing training for entrepreneurs, it is purposed to motivate members to become entrepreneurs. Each year the entrepreneurship training provided varies according to the request of the mem- 
bers, but each training that is held was attended by no more than $5 \%$ of the total number of members (LPJ SBW, 2020).

If the cooperative member is only a housewife, she doesn't need business capital. This is different if the cooperative's members are entrepreneurs as they have businesses, they need business capital, and they will get business capital from the cooperative so they will participate actively to cooperative business. If the cooperative's members who participate actively are more than passive members, it will then affect to performance of cooperative. Of course, a cooperative would like to have entrepreneur members. Based on the explanation above, this study aims to analyze the effectiveness of skills training and motivation in cultivating the growth of entrepreneurial interest on Setia Bhakti Wanita Cooperative's members.

\section{LITERATURE REVIEW}

\subsection{Training and Skills}

According to Simamora (2006: 342), training is a systematic process of changing the behavior of employees in a direction in order to increase the meaning of organizational goals. According to Handoko (2002: 104), training is useful to improve the mastery of various skills and specific work implementation techniques, details, and routine. The expected benefits and impacts of the training must be clearly formulated, not ignoring the ability and capability of the agency. According to Simamora (2004: 348-350), the benefits of training include: (1) Increasing the quantity and quality of productivity. (2) Creating a more profitable attitude, loyalty and cooperation. (3) Reducing the learning time needed by employees to reach acceptable performance standards. (4) Meeting the needs of human resource planning. (5) Reducing the amount of costs and accidents. (6) Assisting employees in their personal improvement and development.

Work skills training is defined by a series of processes of teaching and learning activities that are planned, programmed, and carried out in an effort to increase the practical ability to produce goods and services that can be done formally or informally. In addition, job skills training can increase entrepreneurial interest for participants (Zumala, 2014). Ichsan and Ariyanti (2005: 7), as 
well as the formulation of skills as a form of soft skills which include: communication skills, ability to manage themselves, effective leadership, ability to solve problems, ability to deal with pressure, ability to work in groups, and work ethics.

\subsection{Entrepreneurial Interest}

According to Alwi (2012) and to the Kamus Besar Bahasa Indonesia, the meaning of entrepreneur is the same as being an entrepreneur, that is, someone who is smart or talented who recognizes new products, determines new ways of thinking, determines new ways of production, arranges operations for the procurement of new products, markets, and regulates its operating capital. In essence, entrepreneurship is a creative and innovative ability that is used as the basis, tricks, and resources to create opportunities for success in business or life (Widyana et al., 2018).

Entrepreneurial interest is a sense of interest to become an entrepreneur who is willing to do activities in managing time, skills, and finance for business progress. Entrepreneurial interest is not obtained from birth but grows and develops according to influencing factors (Widyana et al., 2018).

According to Agus Sujanto (2004: 92), interest is a concentration of attention that is accidentally born with a full will and depends on the environmental talent. Meanwhile, according to Deden Setiawan (2016: 11), interest in entrepreneurship is a sense of interest to become an entrepreneur who is willing to work hard and diligently in order to achieve business progress. Hilgard and Bowers (2004: 22) defined interest as: "a persistent tendency to pay attention to and enjoy some activity or content, especially a vocational interest" (The tendency to pay attention and like certain things or activities, especially towards certain things).

Factors that influence the growth of decisions for entrepreneurship are the result of the interaction of several factors, namely the character of a person's personality and environment (Bygrave, 2003). According to Lambing, et al. (2007), there are four things that influence entrepreneurial decisions, namely the personal self, the cultural environment, social conditions, and a combination of the three. Meanwhile, according to Hisrich et al (2005: 18) and Buchari Alma 
(2010: 12), factors that influence entrepreneurial interest are the educational environment, one's personality, and family environment. Interest in entrepreneurship can be seen from two main indicators, namely: (1) how strong is a person's efforts to dare to try entrepreneurial activities; (2) how much effort is planned by someone to carry out entrepreneurial activities (such as activities in managing time and finance for entrepreneurial purposes).

According to Wiedy Murtini (2012: 6-7), characteristics of successful entrepreneurs include; (1) high morale, (2) independence, (3) tenacity and diligence, (4) creativity, (5) innovativeness, (6) high self-confidence, (7) courage to take calculated risks, (8) having a positive reaction to the challenges faced, (9) having the tenacity and strong determination to achieve goals, and (10) having an understanding of the market. The findings of Ishfaq Ahmed et al (2011) stated that structural and social factors affect student interest in entrepreneurship, while economic factors do not affect student entrepreneurial interest. Other than that, personality traits (self-efficacy) have no relationship with external factors and entrepreneurial interest. According to Jianfeng Yang (2013), gender and entrepreneurial experience of parents have a significant impact on entrepreneurial attitudes, subjective norms, perceived behavioral control, and entrepreneurial interests.

\subsection{Motivation}

According to Robbins and Judge, motivation is defined as a process that explains the strength, direction, and perseverance of someone in an effort to achieve goals (Robbins and Judge, 2015: 127). Motivation can also be defined as a strength in a person who pushes or moves him to meet his basic needs and desires (Yorks, 2001: 21). Meanwhile, according to Duttweiler, motivation is a factor that moves, directs, and supports continuously increasing results (Duttweiler, 2006: 371).

Classical literature studies and the latest theories on motivation produce four main theoretical areas: (1) Motivation Theory of Maslow's Hierarchy of Needs, (2) Motivation and Hygiene Theory or Herzberg's Two-factor Theory, (3) McGregor's XY Theory, and (4) Achievement Motivation Theory by McClelland. Maslow stated that people are motivated by unmet needs based on the order of 
importance from the lowest order to the highest order. The most basic category of needs raised by Maslow was self-actualization. This belief is the basis of McGregor's $Y$ theory on assumptions about motivation based on self-regulation, self-control, motivation, and maturity (McGregor, 2000: 47).

The theory of hygiene motivation proposed by Herzberg is often referred to as the two-factor theory and is focused on sources of motivation related to work completion. Herzberg concluded that job satisfaction and dissatisfaction are the result of two different factors (Herzberg, Mousner and Snyderman, 2005: 59): motivating factors (satisfaction) such as Achievement, Rewards, the Work itself, Responsibility, Promotion, and Development; and the dissatisfaction factors, among others: company policy, oversight, working conditions, relationships with others, salary, status, job security, and personal life.

According to Mc. Cleland when someone has strong needs, the impact is motivating someone to use behaviors that lead to meeting the need for satisfaction. The essence of this theory is that needs are learned through adaptation to one's environment. Because needs are learned, given behavior tends to occur at a higher frequency (Gibson, Ivancevich and Donnely, 2007: 111). The need for achievement includes the desire to independently master objects, ideas, or others, and to increase the belief of one's self through skills training.

\subsection{Women Cooperative}

The definition of cooperative is a business entity consisting of individuals or legal entities of cooperatives basing their activities based on cooperative principles as well as a people's economic movement based on the principle of kinship (Menteri Koperasi dan Usaha Kecil Menengah Republik Indonesia, 1992). According to Wikipedia, A cooperative is an economic organization owned and operated by individuals for the common good. According to International Cooperative Alliance (ICA), a cooperative is "An autonomous association of person united voluntarily to meet their common economic, social, and cultural needs and aspirations through a jointly-owned and democratically controlled enterprise' (Rohmat, 2016).

Cooperative-based activities based on the principles of the people's economic movement comes from family principles. As a pillar of the national 
economy, cooperatives are the only form of business contained in Article 33 paragraph (1) of the 1945 Constitution of the Republic of Indonesia. A women's cooperative is a cooperative specifically managed by women and are commonly called Koperasi Wanita (Kopwan) (Sudrajat\& Khoiri, 2018). All members of a women cooperative are women.

Cooperative principles are as follows (Cooperative Law 1992):

a. Membership is voluntary and open; this principle implies that a person to become or not to become a member of a cooperative must not be forced and must be by one's own willingness. The existence of this nature of openness makes cooperatives to know no boundaries and to have no discrimination.

b. Management is carried out democratically; which means that management includes supervision as well. Every member has the same rights and obligations in the cooperative, the right to propose, correct, and ask questions about the management of the cooperative, and at the same time to be chosen and to choose to become a manager or supervisor.

c. The distribution of the remaining results of operations is carried out fairly in proportion to the magnitude of business services each member; remaining operating results are the difference between the income earned and the costs incurred in managing the business. Every member who participated actively in the business will get a share of the profits from the members who are not active.

d. Granting limited compensation for capital; the member is the owner of the cooperative and at the same time is a service user. The capital deposited to the cooperative is basically to serve the members and members will get compensation for the capital invested in accordance with the capabilities of the cooperative.

e. Independence; which means that cooperatives must be able to stand on their own when making business and organizational decisions. Independence also means freedom that is responsible, autonomous, self-reliant, and courageous to take responsibility for their own actions in managing businesses and organizations

f. Cooperative education; The success of cooperatives is closely related to the good quality and broad-mindedness of all lines both administrators, supervisors, members, and employees, so that cooperative education is needed. 
g. Cooperation between cooperatives; by cooperating between cooperatives, it is hoped that they will mutually support and leverage the advantages of cooperatives, and as such, creating synergy.

\section{METHOD}

The research method in this study uses a quantitative approach. Data collected was analyzed statistically. This study uses a form of explanatory research. The population in this study were members of the women's cooperative Setia Bhakti, East Java, who attended the Skills Training in 2019 organized by the cooperative in collaboration with third parties. The attendees are as many as 351 people (bakery skills participants $=207$ people, Eco-print skills participants $=$ 87 people and skills participants Care and Beauty $=57$ people) (LPJ SBW, 2019). After it was classified out of 351 participants, many participants took 2 types of skills training or even participated in all three training sessions held, so the population was only 140 people, and the number of samples taken was 100 . This number is determined based on Isaac and Michael's theory with an error rate of $5 \%$. The sampling technique used in this study is random sampling.

The research instrument used was a questionnaire to measure all the variables to be tested using a Likert scale and the indicator used ranged from one to five to show trends from "strongly disagree" to "strongly agree". The type of data used in this study is primary data, where the source of data is obtained through a questionnaire given to participants in 2019 skills training, both bakery, eco-printing, and beauty and care skills.

The regression model of this study is:

$$
\mathrm{Yi}=\mathrm{a}+\mathrm{b} 1 \mathrm{X} 1+\mathrm{b} 2 \mathrm{X} 2
$$

$\mathrm{Yi}=$ is interested in being an entrepreneur. $\mathrm{i}$ is an indicator of entrepreneurial interest, namely: (1) the desire to work independently, (2) the desire to get challenges, (3) the desire to obtain a decent and stable income, and (4) the desire to create something new. Each indicator is given a value on a scale of 5 .

$\mathrm{a}=$ is the constant value of $\mathrm{b} 1$ and $\mathrm{b} 2$ of the regression coefficient 
$\mathrm{X} 1=$ is the entrepreneurship training variable, valued at 1 to 5

$\mathrm{X} 2=$ is a motivation variable, valued at 1 to 5

\subsection{Results and Discussion}

This research was conducted at the Setia Bhakti women's cooperative, East Java, located at Jalan Jemur Andayani No. 55 Surabaya. This cooperative always provides different skills according to the members' requests every year. This skills training is held so that members get additional skills/experience to start new businesses or develop their existing businesses. The data to be analyzed is the data from the skills training participant questionnaire conducted by the Setia Bhakti Women's Cooperative in East Java during 2019.

In this discussion, the research will describe the respondents who used for the sample in this study. The sample used in this study were 100 respondents. All respondents were female and aged between 20-60 years. The table below shows respondents characteristics based on age:

\begin{tabular}{|c|c|c|c|}
\hline \multirow{2}{*}{ No. } & \multirow{2}{*}{ Age } & \multicolumn{2}{|c|}{ Respondents } \\
\cline { 3 - 4 } & $20-30$ & People & Percent \\
\hline 1 & $31-40$ & 50 & $10 \%$ \\
\hline 2 & $41-50$ & 25 & $50 \%$ \\
\hline 3 & $51-60$ & 15 & $25 \%$ \\
\hline 4 & TOTAL & 100 & $100 \%$ \\
\hline & \multicolumn{2}{c}{} \\
\hline
\end{tabular}

From the table, it can be seen that most respondents or $50 \%$ who participated in the training were $31-40$ years old. Also, from the results of the questionnaire responses filled by respondents, after being classified who are interested in entrepreneurship based on age are 31-40 years old, while the respondents who are interested in entrepreneurship are at least 20-30 years old, because they prefer to work as employees.

\section{Research Instrument Testing}

To find out the results of the study, a valid and reliable instrument is needed. A valid instrument means that the measuring instrument used to get the data 
(measuring) is valid, whereas a reliable instrument is an instrument that, if used several times to measure the same object, will produce the same data. In detail, the results of testing the research instruments are presented, as follows:

\section{Validity test}

The validity test has been done to 60 respondents. The results of the validity test analysis can be known after performing calculations using the SPSS program and the results show that all items of each statement have a significance value of $(>0.05)$. Therefore, the entire item is declared valid.

\section{Reliability Test}

A questionnaire is said to be reliable if a person's answer to a statement is consistent or stable from time to time. Reliability test using the Cronbach's alpha technique, stating that the instrument has a high reliability value if the Cronbach's alpha value is $>0.6$. This is shown in the table below:

Reliability Statistics

\begin{tabular}{|r|r|}
\hline Cronbach's Alpha & \multicolumn{2}{|c|}{ N of Items } \\
\hline .858 & 18 \\
\hline
\end{tabular}

Cronbach's alpha reliability coefficient values are more than 0.6. The calculated value is greater than the $r$ count table, so it can be concluded that the instrument or questionnaire used is very reliable.

\section{Classic assumption test}

\section{Normality test}

Normality test is needed to test other variables by assuming that the residual value follows normal distribution. The normal distribution of data can be determined by using a normal plot graph by looking at the histogram of the residuals. Basic decision making (Ghozali, 2011: 163) is "If the data spreads 
around the diagonal line and follows the direction of the diagonal line or the histogram graph, then this shows a normal distribution pattern, and thus the regression model fulfills the assumption of normality".

The following graph is the normal plot of the analysis:

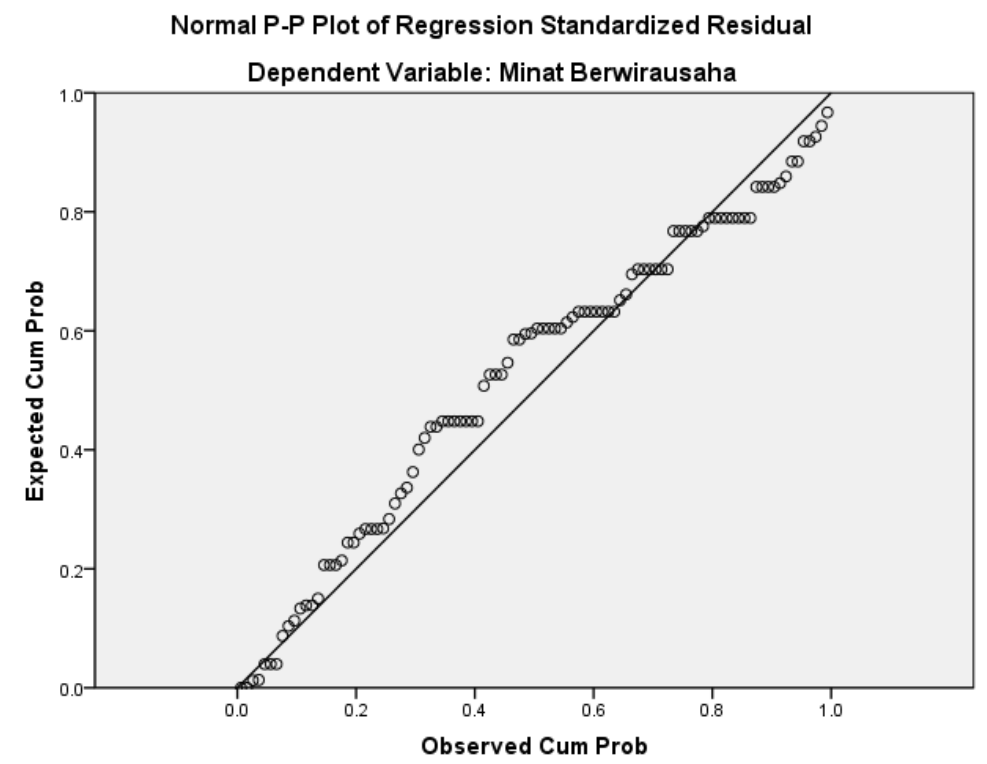

\section{Multi Collinearity Test}

According to Imam Ghozali (2013: 105) multicollinearity test aims to test whether the regression model found a correlation between independent variables. Multicollinearity test is used to test whether the regression model found a correlation between independent variables (independent). From the test results, the VIF values obtained are shown in the table below:

\section{Coefficients $^{\mathrm{a}}$}

\begin{tabular}{|ll|r|c|}
\hline \multirow{2}{*}{\multicolumn{2}{|c|}{ Model }} & \multicolumn{2}{c|}{ Collinearity Statistics } \\
\cline { 2 - 3 } & Tolerance & \multicolumn{1}{c|}{ VIF } \\
\hline 1 (Constant) & & \\
& Pelatihan Keterampilan & .801 & 1.248 \\
Motivasi & .801 & 1.248 \\
\hline
\end{tabular}

a. Dependent Variable: Entrepreneurial interest 
The table above shows skills training variable $(\mathrm{X} 1)$ of $1.248(1.248<10)$ and Motivation Variable $(\mathrm{X} 2)$ of $1.248(1.248<10)$. Therefore, it can be said that the multiple linear regression is used in this study is free from multicollinearity and as such, the data is worth analyzing.

\section{Heteroscedasticity Test}

Heteroscedasticity is a condition where there is an inequal variance of residuals in the regression model. A good regression model requires the absence of heteroscedasticity problems. The analysis of the Heteroscedasticity Test is described as follows:

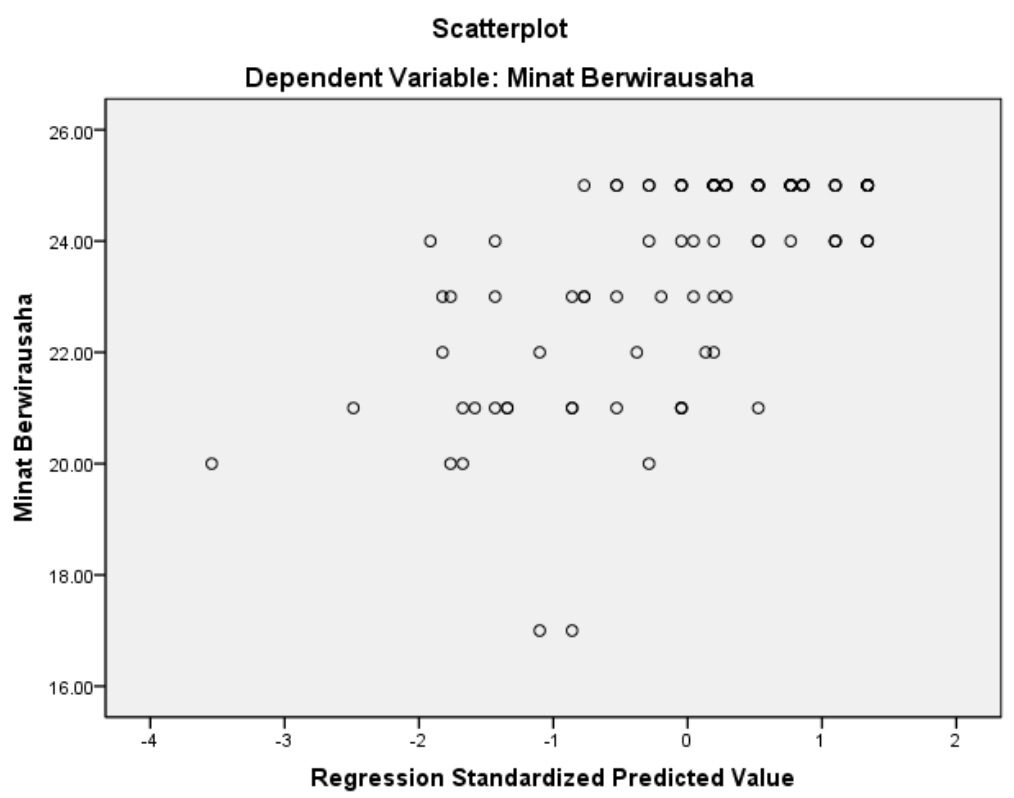

\section{Autocorrelation Test}

In this study, researchers used the Durbin-Watson (DW test) approach because the sample used was less than 100. If the sample is over 100, then the Lagrange Multiplier (LM test) approach must be used. Autocorrelation test is used to determine whether or not there is an assumption of classic autocorrelation, which is the correlation that occurs between residuals in one observation with other observations in the regression model, such as shown in the table below: 
Model Summary ${ }^{\mathrm{b}}$

\begin{tabular}{|l|r|r|r|r|r|}
\hline Model & \multicolumn{1}{|c|}{ R } & R Square & \multicolumn{1}{c|}{$\begin{array}{c}\text { Adjusted R } \\
\text { Square }\end{array}$} & $\begin{array}{c}\text { Std. Error of } \\
\text { the Estimate }\end{array}$ & Durbin-Watson \\
\hline 1 & $.637^{\mathrm{a}}$ & .405 & .393 & 1.45245 & 1.486 \\
\hline
\end{tabular}

a. Predictors: (Constant), skills training, motivation

b. Dependent Variable: entrepreneurial interest

The DW (Durbin-Watson) value is 1.486, greater than the limit (DU). Thus, it was concluded that there are no symptoms of autocorrelation. This means that multiple regression used in this study was not affected by autocorrelation and the data is feasible for analysis.

\section{Multiple Linear Regression Analysis}

From the results of multiple linear regression analysis, the magnitude of the constants and the regression coefficients were obtained for each variable, as follows:

From the table above, the following results are obtained:

$$
\mathrm{Y}=1.050+0,680 \mathrm{X} 1+0,286 \mathrm{X} 2
$$

The regression equation can be described as follows:

1. Constant value $(\alpha)$ of 1.050 , stating that if the training skills and motivation variables are 0 , then the entrepreneur interest variable is 1.050 .

2. The coefficient of the independent variable (X1) of 0.680 indicates that every $1 \%$ increase in training skill will be followed by an increase in entrepreneur interest by 0.680 .

3. The coefficient of the independent variable (X2) of 0.286 indicates that every $1 \%$ increase in motivation will be followed by an increase in entrepreneur interest by 0.286 .

From the results of data processing, the calculated $\mathrm{F}$ value is 33.031 with a significance value of 0.00 which is less than 0.05 . Thus, the results of the analysis show that all independent variables, namely the skills training variable 
Iwang Suwangsih / Analysis of the Effectiveness of Skill Training and Motivation on the Growth of Entrepreneurial Interest on Members of Setia Bhakti Wanita East Java Women Cooperative

(X1) and motivation variable (X2) simultaneously have significant influence on entrepreneurial interest $(\mathrm{Y})$.

\section{T-test}

Tests were carried out using a significance level of 0.05 ( $\alpha=5 \%)$. Acceptance or rejection of the hypothesis is based on the criteria:

1. If the value is significance $>0.05$, then the hypothesis is rejected (the regression coefficient is not significant). It means that partially independent variables do not have a significant effect on the dependent variable.

2. If the significance value $\leq 0.05$, the hypothesis is accepted (significant regression coefficient). It means that partially independent variables have a significant relationship to the dependent variable.

The Result of t-Test Analysis

Coefficients $^{\mathrm{a}}$

\begin{tabular}{|c|c|c|c|c|c|}
\hline \multirow{2}{*}{ Model } & \multicolumn{2}{|c|}{ Unstandardized Coefficients } & $\begin{array}{l}\text { Standardized } \\
\text { Coefficients }\end{array}$ & \multirow[t]{2}{*}{$\mathrm{t}$} & \multirow[t]{2}{*}{ Sig. } \\
\hline & B & Std. Error & Beta & & \\
\hline $1 \quad$ (Constant) & 1.050 & 2.796 & & .376 & .708 \\
\hline Skills Training & .680 & .120 & .494 & 5.651 & .000 \\
\hline (Motivation) & .286 & .106 & .237 & 2.709 & .008 \\
\hline
\end{tabular}

Source: SPSS result

a. T-test between the skills training variable (X1) with entrepreneurial interest (Y) produces a significance value of $\mathrm{t}<0.00<$ alpha 0.05 . Thus, H0 is rejected and $\mathrm{H} 1$ is accepted, concluding that partially (individually), the skills training has a significant relationship towards entrepreneurial interest.

b. T-test between the motivational variable (X2) with entrepreneurial interest (Y) produces a significance value of $\mathrm{t}$ of $0.05<$ alpha 0.05 . Thus, H0 is accepted and $\mathrm{H} 1$ is rejected, concluding that partially (individually) motivation no has a significant relationship towards entrepreneurial interest.

\section{F-test}

The simultaneous influence test (F-test) is used to find out whether independent variables as a whole or simultaneously have a relationship with the 
dependent variable. The F-test analysis basically shows whether all independent variables used as models have a positive and significant relationship as a whole (simultaneously) to the dependent variable. If the significance value is $<$ alpha 0.05 (5\%), then $\mathrm{H} 0$ is rejected and $\mathrm{H} 1$ is accepted.

Table 1 The Result of F-test Analysis

ANOVA $^{\mathrm{b}}$

\begin{tabular}{|l|r|r|r|r|r|}
\hline \multicolumn{1}{|c|}{ Model } & Sum of Squares & df & Mean Square & F & Sig. \\
\hline Regression & 139.367 & 2 & 69.683 & 33.031 & $.000^{\mathrm{a}}$ \\
Residual & 204.633 & 97 & 2.110 & & \\
Total & 344.000 & 99 & & & \\
\hline
\end{tabular}

a. Predictors: (Constant),

b. Dependent Variable: entrepreneur interest

The F-test table between variables $\mathrm{X} 1$ and $\mathrm{X} 2$ with variable $(\mathrm{Y})$ produces a significant value of $0,000<$ alpha 0.05 , and thus $\mathrm{H} 0$ is rejected and $\mathrm{H} 1$ is accepted. It can be concluded that variables X1 and X2 simultaneously have a significant relationship to entrepreneurial interest.

\section{DISCUSSION}

From the results of the statistical analysis, the $t$ value of the training skills variable of 5.651 with a significance value of 0.00 means that the skills training variable (X1) has a partial effect on entrepreneurial interest $(\mathrm{Y})$. On the other hand, the result of the analysis of the motivation variable t value is 2.709 with the significance value of 0.08 shows that the motivation variable (X2) has no partial effect on entrepreneurial interest $(\mathrm{Y})$ because the significance value is greater than 0.05 .

Skills training has a partial significant influence on the entrepreneurial interests of members of women's cooperatives because the type of skills training is organized in accordance with the requests or wishes of members so that it is an opportunity for members to gain new experience and insights that will be used as provisions in opening new businesses (entrepreneurship) or in developing 
existing businesses. Members may even take skills training to a higher level to further explore the material even at their own expense. On the other hand, motivation does not have a partial significant effect because motivation is influenced by internal factors (from within the individual itself) and external (environment). Motivation from within the individual is the most encouraging for entrepreneurial interest, which is the determination or strong intention to develop the business. In this case, many respondents are still hesitant to become entrepreneurs for the fear of the inability to work constantly.

This finding supports the findings of Maryani et.al (2018) which stated that the effect of entrepreneurship education (skills training) on entrepreneurial interest is 98.6\% (Maryani et.al, 2018). Anggareni and Harnanik's findings also stated that there is a positive influence of entrepreneurship knowledge on the interest of entrepreneurship in XI grade students of Islamic Vocational Schools (Anggraeni \& Harnanik, 2015). The result of a study by Luh et al. (2014) shows that there is significant effect of entrepreneurship education toward students' interest in entrepreneurship as seen from the correlation of the effect, which is 0,628 (Luh, Prayantini, Nuridja, \& Indrayani, 2014).

The results of this study are the opposite of the results of the research conducted by Rahmi and Hidayati (2019). Their findings stated that the motivational variable has a partial significant effect on entrepreneurial interest because respondents have a strong determination to run businesses, whereas skills training does not have a significant effect because the skills training carried out are short courses with less in-depth understanding of the material.

While the results of FM Dewi's study (2016) showed that there was a positive but not significant influence between the participation of Kopma members on the entrepreneurial interest of FIS students in Kopma UNY members. This is evidenced by the calculated r-value of 0.214 , which is greater than r-table of 0.19 . The effect of the participation of student cooperative members on student entrepreneurial interest in this study had a coefficient of determination (R2) of 0.046 or $4.6 \%$. This means that the variance that occurs in the student entrepreneurial interest variable is influenced by the participation of student cooperative members by $4.6 \%$. 


\section{CONCLUSION}

Based on the results of data analysis and discussion in the previous chapter, the conclusions of this study are as follows:

1. Skills training is a very beneficial activity for members of the Setia Bhakti East Java women's cooperative to increase both knowledge and experience that can foster entrepreneurial interest or to develop their business because skills training is selected in accordance to the wishes of members.

2. Simultaneously, skills training and motivation have a significant influence on the entrepreneurial interests of the members of the Setia Bhakti Women's Cooperative in East Java.

3. Partially, only skills training has a significant influence on the entrepreneurial interests of members of the East Java Women's Setia Bhakti Women's Cooperative.

4. Skills training has a positive relationship with entrepreneurial interest. The results are obtained using the t-test, where the results state a significance value of 0.00 . Therefore, the hypothesis is accepted and proven as true.

5. Motivation has a positive relationship with entrepreneurial interest. The results are obtained using the t-test, where the results state that the motivation variable has a significance value of 0.05 . Therefore, the hypothesis is accepted and proven as true.

6. Skills training and motivation have a positive relationship with entrepreneurial interest as evidenced by the F-test which has a significance value of 0,000 , which is smaller than 0.05 .

\section{REFERENCES}

Anggraeni \& Harnanik. 2015. Pengaruh Pengetahuan Kewirausahaan dan Lingkungan Keluarga Terhadap Minat Berwirausaha Siswa Kelas XI SMK Islam Nusantara Comal Kabupaten Pemalang. Dinamika Pendidikan, 10(1), 42-52. https://doi.org/10.15294/dp.v10i1.5093.

Josia Sanchaya Hendrawan, H.S. 2017. Pengaruh Sikap Mandiri, Motivasi, Pengetahuan Kewirausahaan Terhadap Minat Berwirausaha (Studi Kasus 
pada Mahasiswa FEB UKSW Konsentrasi Kewirausahaan). Asian Journal of Innovation and Entrepreneurship, 02(03), 291-314.

FM Dewi. 2016. Penagruh Partisipasi Anggota Koperasi Mahasiswa Terhadap Minat Berwirausaha Mahasiswa FIS Anggota Kopma UNY. Social Studies, 2016- journal student.uny.ac.id.

Luh, N., Prayantini, D., Nuridja, M., \& Indrayani, L. 2014. Pendidikan Ekonomi Universitas Pendidikan Ganesha. Ganesha, 9(2).

Maryani et al. 2018. Penghuni Lapas Perempuan di Pontianak Artikel Penelitian oleh: Heni Maryani Program Studi Magister Pendidikan Ekonomi Universitas Tanjungpura Pontianak the Influence of Education and Training Entrepreneurship Against the Interest of Entrepreneurship Pris.

Menteri Koperasi dan Usaha Kecil Menengah Republik Indonesia. 1992. UndangUndang Republik Indonesia Nomor 25 Tahun 1992. Tentang Perkoperasian, 1-28. https://doi.org/10.1590/s1809-98232013000400007.

Munir, Z.A., Idrus, S., Shukur, S.A.M., Ithnin, R., \& Mohamad, S.S. 2015. The Effectiveness of Entrepreneurial Motivational Training Programme among University Students. International Journal of Social Science and Humanity, 5(5), 487-490. https://doi.org/10.7763/ijssh.2015.v5.505.

Rahmi, V.A. \& Hidayati, R.A. 2019. Efektivitas Pelatihan Keterampilan dalam Menumbuhkan Minat Wirausaha Wanita Melalui Motivasi Diri Berwirausaha. JMK (Jurnal Manajemen dan Kewirausahaan), 4(1), 1. https:/ /doi.org/10.32503/jmk.v4i1.350.

Rohmat, A.B. 2016. Analisis Penerapan Prinsip-Prinsip Koperasi dalam UndangUndang Koperasi (Studi Undang-Undang No. 25 Tahun 1992 dan UndangUndang No.17 Tahun 2012). Jurnal Pembaharuan Hukum, 2(1), 138. https://doi.org/10.26532/jph.v2i1.1424.

Sudrajat, M.A. \& Khoiri, M.T. 2018. Analisis Tingkat Kesehatan Koperasi Wanita di Kota Madiun. Inventory: Jurnal Akuntansi, 1(2), 116. https:// doi.org/10.25273/inventory.v1i2.2436.

Sugiarto, J., Wismanto, Y.B., \& Utami, C.T. 2015. Efektivitas Pelatihan Entrepreneurship Skill untuk Meningkatkan Minat menjadi Entrepreneur. PrediksiKajian Ilmiah Psikologi, 4(1), 51-60.

Widyana, I.W., Widyawati, S.R., \& Warmana, G.O. 2018. Pengaruh Pemberian Mata Kuliah Kewirausahaan dan Pelatihan Wirausaha terhadap Minat 
Review of Management and Entrepreneurship

Volume 04, Number 01, April 2020

Wirausaha Ekonomi Kreatif pada Mahasiswa Unmas Denpasar. Jurnal Bakti Masyarakat Indonesia, 1(1), 171-177.

https://keuangan.kontan.co.id/news/jumlah-koperasi-aktif-perempuan-indonesiacapai-13000-unit. 